\title{
Effects of dietary fiber intake on inflammation in chronic diseases
}

\author{
Efeitos da ingestão de fibras sobre a inflamação nas doenças crônicas
}

\author{
Ana Maria Pita Lottenberg ${ }^{1}$, Patricia Luriko Tomita Fan², Vivian Buonacorso
}

\begin{abstract}
Chronic diseases such as obesity, type-2 diabetes, metabolic syndrome and cardiovascular diseases are associated with inflammation due the increase of TNF- $\alpha$, IL-6 and C-reactive protein concentrations. Occidental life style, specially related to the changes in food habits as observed in the past years, have an important role in the development of these diseases. Among the life style changes identified as having an impact in the development of diseases, is the decrease in dietary fiber consumption. Some studies have shown the negative relationship between fiber ingestion and inflammatory markers in chronic diseases. Dietary fibers have an important and a well-known role in different physiologic functions such as intestinal peristalsis, weight reduction by acting on satiety mechanisms, preventing colon cancer, reducing cholesterol and post-prandial glycaemia.
\end{abstract}

Keywords: Dietary fiber; Inflammation; Biological markers; Obesity; Diabetes Mellitus; Metabolic diseases

\section{RESUMO}

Doenças crônicas como obesidade, diabetes, síndrome metabólica e doenças cardiovasculares têm sido associadas a processos inflamatórios, pois se tem observado aumento nas concentrações de alguns marcadores inflamatórios, como TNF- $\alpha$, IL- 6 e proteína C-reativa nessas condições. 0 estilo de vida ocidental, especialmente no que diz respeito à mudança nos hábitos alimentares observada nos últimos anos, tem papel importante no desenvolvimento dessas doenças. Entre as alterações de hábitos alimentares identificados como impactantes para 0 desenvolvimento de doenças crônicas, está a redução no consumo de fibras alimentares. Alguns estudos têm mostrado relação negativa entre ingestão de fibras alimentares e marcadores inflamatórios associados às doenças crônicas. As fibras alimentares têm papel importante nas diversas funções fisiológicas já conhecidas como: peristaltismo intestinal, emagrecimento, influenciando os mecanismos de saciedade, preventivo no câncer de cólon, coadjuvante para o controle de colesterol e redução glicemia pós-prandial.

Descritores: Fibra alimentar; Inflamação; Marcadores bioquímicos; Obesidade; Diabetes Mellitus; Doenças metabólicas

\section{INTRODUCTION}

We already know some benefits of dietary fibers to human health. The regular intake of fibers in food plays important roles in the body in bowel function, increasing the fecal bolus and reducing transit time along the bowel $^{(1)}$; it helps reducing the plasma LDL-cholesterol by increasing the fecal excretion of cholesterol and biliary acids ${ }^{(2)}$; it reduces post-prandial glucose levels of healthy individuals, diabetics and those with insulin resistance ${ }^{(3)}$; it reduces the risk of developing some types of cancer ${ }^{(4)}$; it brings about satiety ${ }^{(3)}$; helps to loose weight $^{(5)}$; and has an immunomodulating effect ${ }^{(6)}$.

It seems that the ingestion of fibers also brings benefits in inflammatory processes ${ }^{(7-9)}$ that have been associated with chronic disorders such as the metabolic syndrome (MS), obesity, type 2 diabetes mellitus (DM2), cancer and cardiovascular diseases $(\mathrm{CVD})^{(10,11)}$. These disorders are strongly associated with the Western world lifestyle and related to increased ingestion of processed (refined) foods, larger amount of fat ${ }^{(12)}$ and reduced intake of fibers ${ }^{(13)}$. An association between ingestion of fibers and its role in chronic diseases, in which inflammation is present, was suggested by some authors $^{(14-15)}$.

\footnotetext{
PhD in Food Sciences; Dietitian of the Department of Endocrinology of Hospital das Clínicas da Faculdade de Medicina da Universidade de São Paulo - USP; Coordinator of the Specialization Course in Nutrition in Non-communicable Chronic Diseases of Instituto Israelita de Ensino e Pesquisa Albert Einstein - IIEPAE, São Paulo (SP), Brazil.

${ }^{2}$ Master's degree student in Health Sciences from the Department of Clinical Endocrinology at Universidade Federal de São Paulo - UNIFESP, São Paulo (SP), Brazil.

${ }^{3}$ Master's degree in Sciences; Preceptor of the Specialization Course in Nutrition in Non-communicable Chronic Diseases of Instituto Israelita de Ensino e Pesquisa Albert Einstein - IIEPAE, São Paulo (SP), Brazil.

Corresponding author: Ana Maria Pita Lottenberg - Faculdade de Medicina da USP - Avenida Dr. Arnaldo, 455, sala 3317 - Cerqueira César - CEP $01246-903$ - São Paulo (SP), Brazil - e-mail:

amlottenberg@uol.com.br

Received on Apr 27, 2009 - Accepted on Apr 12, 2010

Conflict of interest statement: The authors declare there is no conflict of interest in any field related to the preparation of this paper.
} 
Thus, this paper presents the association between dietary fibers and inflammatory process markers (IM), and their possible mechanism of action.

\section{Chronic diseases and inflammation}

The immune and metabolic systems are closely related and act in an interdependent fashion. Many hormones, cytokines, signaling proteins, transcription factors and bioactive lipids are capable of activating both systems, in such a way that fat tissue starts secreting pro-inflammatory substances, which before were associated solely with the immune system, such as interleukin 6 (IL-6), tumor necrosis factor alpha $(\mathrm{TNF}-\alpha)^{(10)}, \mathrm{C}$-reactive protein (CRP) and plasma plasminogen activator inhibitor (PAI1) ${ }^{(16)}$.

The inflammatory processes are strongly associated with excessive fat tissue, and such relation is explained by interaction among the systems. The pro-inflammatory activity of fat tissue represents a potential risk towards the development of other chronic diseases and their complications $^{(11,17)}$.

\section{Metabolic Syndrome}

Metabolic syndrome (MS) is defined when there are numerous metabolic abnormalities happening concurrently to one individual who present at least three of the following conditions: insulin resistance, abdominal obesity, hypertension or dyslipidemia ${ }^{(13,18-19)}$. The NCEPATPIII (National Cholesterol Education Program - Adult Treatment Panel III) also includes, as MS components: the pro-inflammatory status (characterized by an increase in C-reactive protein) and a prothrombotic status (because of increased PAI1 and fibrinogen) ${ }^{(19)}$.

Globally, the number of individuals with MS is on the rise, and such progressive growth is associated with a higher incidence of obesity and DM2 on the population $^{(18)}$.

Interestingly, some studies showed the relation of inflammatory process characteristic factors and MS, reporting that the more syndrome factors present, the greater the levels of inflammatory cytokines. Inflammatory markers (IM) have also been associated with an increased mortality risk, besides that of CVD in $\mathrm{MS}^{(20)}$.

\section{Obesity}

Obesity and its consequences are growing problems all over the world leading to great loss to health of human beings ${ }^{(12)}$.

There is a strong correlation between increased in body weight - either overweight or obesity, increased fat tissue and activation of inflammatory mechanisms ${ }^{(11)}$.
The fat tissue of obese individuals has adipocytes and macrophages which interact simultaneously (Figure 1), where one starts to perform the protein synthesis of another; in other words, adipocytes start to produce pro-inflammatory proteins (such as TNF- $\alpha$ and IL-6), while macrophages start to produce lipid metabolism proteins, such as FABPs (fat acid binding protein) and PPARy (peroxisome proliferator-activated receptor gamma $)^{(11)}$.

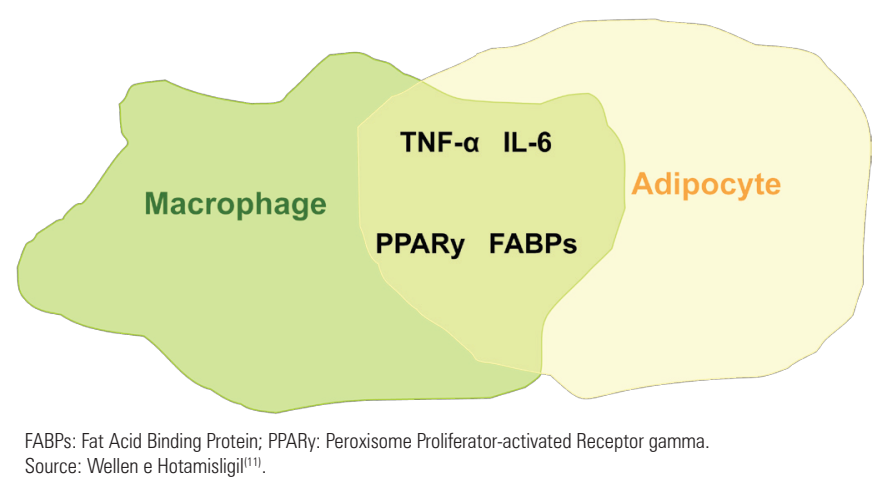

Figure 1. Co-localization of adipocytes and macrophages in fat tissue: macrophages start synthesizing proteins that are characteristic of adipocytes, which, in turn, synthesize inflammatory cytokines and establish the inflammatory process.

A frequently present harmful consequence of this integration between lipid metabolism proteins and immune system proteins is alteration in insulin activity, which represents an additional risk to the development of DM2 $2^{(16-17)}$.

\section{Diabetes Mellitus}

Obesity and the characteristic factors of MS are closely associated with the higher risk of developing $\mathrm{DM} 2^{(18)}$.

Within the inflammatory process, insulin activity is impaired by inflammatory cytokines, which seem to play a fundamental role in this disorder ${ }^{(11)}$, and such conditions seems to be key to activate mechanisms associated with the development of DM2 in the individuals with hereditary predisposition, first by triggering insulin resistance and then the impairment to its secretion. Real and Pickup suggested that concerning DM2 etiology, the innate immune system is activated as a survival response which enables the body to recover from injuries, and when such response is not proportional to the injury, the disease appears ${ }^{(21)}$.

HotamisligilandWellen putforward thatendoplasmic reticulum stress generated from inflammatory cytokines - which impairs insulin action, is the basis for DM2 development ${ }^{(11)}$.

Even with no detailed knowledge about the consequences of DM2 and their association with 
inflammation, it is possible to infer that DM2 etiology is directly or indirectly associated with the inflammatory process.

\section{Heart diseases}

Among chronic diseases, cardiovascular diseases (CVD) represent the major cause of death worldwide. Heart-related diseases are associated with inflammatory processes, especially because of the effect of low density lipoproteins, mainly LDL-cholesterol, that induce inflammation on the endothelium of arteries, resulting in atherosclerotic complications ${ }^{(11)}$.

The IM are largely used to predict the risks of developing heart diseases. CRP (C-reactive protein) is a known inflammatory marker used to predict the incidence of $\mathrm{CVD}^{(22)}$. IL-6 is strongly associated with CVD, and its high levels can point out a future myocardial infarction in healthy individuals ${ }^{(23)}$; and leukocyte count is very often used because, when elevated, they can be associated with $\mathrm{CVD}^{(24)}$.

Obesity is one of the main contributors to CVD, predisposing patients to all sorts of coronary vascular abnormalities: hypercholesterolemia, atherosclerosis, platelet dysfunction, coagulation disorders, insulin resistance, MS and DM2, which are associated with inflammatory processes ${ }^{(25)}$. Thus, we notice this close relation between MS, obesity, DM2 and CVD factors, including the relation between these disorders and inflammatory processes, showing their relevant role in the etiology of these disorders.

\section{Dietary fibers versus inflammation in chronic disorders}

As part of the review and development of the DRIs (Dietary Reference Intake), in 2002, the Institute of Medicine (IOM) proposed the following redefinition: dietary fibers are the edible, indigestible part of carbohydrate and lignin that are intrinsic and intact in the plant. Foods with dietary fibers include: green and yellow vegetables, fruits and whole grains. Functional fibers are those which bring about benefits similar to those from dietary fibers; however, they are isolates or extracts from natural or synthetic sources. The functional fibers include pectin extracted from citric fruits, pulp extracted from trees and other types of isolate fibers. This definition of functional fibers intends to exclude products that are similar to fibers but do not provide benefits to health (defined as having laxative properties, mitigating hypercholesterolemia and hyperglycemia). Total fiber is the sum of the food dietary and functional fibers ${ }^{(26-27)}$.

Some studies pointed to the beneficial relation between ingestion of dietary fibers and inflammatory processes.

\section{Epidemiological studies}

Ma et al. assessed the relation between fiber ingestion and IM in postmenopausal women in the Women's Health Initiative Observational Study. The population of women with higher ingestion of fibers ( $24.7 \mathrm{~g} /$ day) as compared to those with lower ingestion ( $7.7 \mathrm{~g} /$ day $)$ had lower plasma IL-6 and TNF- $\alpha-R 2$ (receptor 2 of the TNF- $\alpha$ ) levels. There was no association between fibers and $\mathrm{CRP}^{(18)}$.

Ajani et al. also observed a lower CRP concentration in individuals from the National Health and Nutrition Examination Survey (NHANES) study (data collected between 1999 and 2002) who ingested higher amounts of fiber daily (32 g), when compared to individuals of lower fiber ingestion $(5.1 \mathrm{~g})^{(9)}$.

Likewise, assessing the fiber ingestion of 5,496 individuals from different ethnical groups, it was noticed that those who ingested more fibers (1.39 $\mathrm{g} /$ serving of food) when compared to those with the least ingestion of fibers $(0.02 \mathrm{~g} / \mathrm{serving})$ were favored with lower CRP values, although this relation was not noticed for IL-6 $6^{(13)}$. The mechanisms through which the ingestion of fibers would reduce $\mathrm{CRP}$ concentrations are still unclear; however, many possibilities are being considered, as the fiber action of delaying glucose absorption and the cytokine modulation mitigating hyperglycemia, acting upon the oxidative stress, favoring intestinal flora response and producing antiinflammatory cytokines ${ }^{(28)}$.

Qi et al. analyzed the ingestion of fibers and inflammation markers on diabetic women of the Nurse's Health Study and concluded that those consuming more fibers had lower values of IM (CRP and TNF- $\alpha-R 2)^{(29)}$. Fiber-rich food, more specifically whole grain, are food types with many bioactive components, such as minerals, vitamins, phytoestrogen, phytoesterol, phenolic compounds and antioxidants, and these can be responsible for its protective effect. The synergic activity of these components present on the cell wall of whole grains provides such effect, reducing the risks of diabetes and heart disease ${ }^{(30)}$.

Jensen et al. did not find statistically significant associations between the ingestion of $43.8 \mathrm{~g}$ /day of fiber (compared to $8.2 \mathrm{~g} /$ day) and IM, except for the lower values of homocysteine among 938 healthcare professionals analyzed in the study. The authors made numerous observations concerning these results, stating that many factors may have an impact on the study result, such as group homogeneity, better conditions of the subjects assessed to acquire fiber-rich food, the fact that they were healthcare professionals, statistical errors in the measures of randomization, only one measure of biomarkers analyzed, and the inflammation biomarkers are susceptible to variation at short term ${ }^{(30)}$.

Jacobs Jr et al. analyzed the data from 27,312 women from the Iowa Women's Health Study and observed 
an inverse association between inflammatory diseases (neither cancer nor cardiovascular diseases), infection and oxidative stress versus the ingestion of 19 servings of fiber per day (compared to 3.5 servings/day) ${ }^{(31)}$. Oxidative stress was associated to an early development of atherosclerosis ${ }^{(15)}$ and, more recently, to post-prandial glucose fluctuations, resulting in chronic hyperglycemia in diabetic patients ${ }^{(32)}$. The antioxidants present in whole grains may contribute to the oxidative processes found in these conditions.

In general, the population studies described above point to an epidemiological association between the high ingestion of fibers (obtained by means of food questionnaires) and a better IM profile. We still have to find out whether or not behind this association there is a causal association with fibers, which can only be answered by means of experimental and clinical studies.

\section{In vitro and clinical studies}

Salman et al. incubated mononuclear blood cells from donors of a blood bank, with and without citrus pectin a soluble citric fruit fiber - in order to assess the impact of such fiber on IM (TNF- $\alpha$, IL1-B, IL-6) and antiinflammatory markers (IL1-a and IL-10) stimulated by a lipopolysaccharide. Inflammatory process inhibition was found, since there was a stimulus to produce antiinflammatory cytokines and inhibit the pro-inflammatory activity cytokine, IL1-B ${ }^{(7)}$. Although the study did not show alterations concerning TNF- $\alpha$ and IL-6, another perspective of the fiber action can be observed, that is, stimulating the production of anti-inflammatory cytokines.

King et al. evaluated the effects of a fiberrich diet (30 g/day, DASH diet) in comparison to the supplementation by psyllium (30 g/day) on the CRP concentrations in eutrophic individuals. There was a CRP reduction in both interventions, compared to baseline and, as far as the DASH diet is concerned, the reduction was by $14 \%$ and for psyllium supplementation, it was by $18 \%{ }^{(28)}$. Another study with psyllium supplementation ( 7 or $14 \mathrm{~g}$ /day) assessed IM (CRP, IL-6, white cells and fibrinogen) from overweight individuals and did not report alterations in any of the markers ${ }^{(14)}$. Between the two types of studies, there is a difference in the quantity supplemented of the same type of fiber. Although there are many other factors that could have influenced this result, one can infer that there is a minimum required for an effective psyllium supplementation over IM.

Prevention and improvement of inflammatory processes associated with chronic diseases happen as a consequence of factors associated with weight control, practice of physical exercises ${ }^{(33)}$, a balanced diet with macronutrients ${ }^{(34)}$, reduction in the ingestion of saturated fat and trans fat ${ }^{(35)}$, appropriate ingestion of fruits and vegetables ${ }^{(36)}$, reduction in the ingestion of possessed and industrialized food and increase in fiberrich foods ${ }^{(37)}$.

Considering the strong relation between inflammation and chronic diseases, one can infer that, for instance, an improvement in the patient's lipid panel will inhibit CVD development, or loosing weight will very likely increase insulin sensitivity and will help maintain proper blood pressure and also a better lipid profile $^{(12)}$. By the same token, inflammatory processes are associated with chronic disorders and must reduce as a response to all globally favorable intervention. The same rationale can be applied to food interventions which favor metabolic improvements.

Few studies identified the causal relation between ingestion or supplementation of fibers with IM reduction. So far, the literature just provides an epidemiological association indicating a strong likelihood of these fibers acting on the metabolic profile of the individuals. Many studies are being done in order to clarify this association, given its importance and the topical issue.

Even if we find a causal relation between fibers and IM, we stress that it is necessary to consider the individual tolerance in clinical practice as to the gastrointestinal effects for greater amounts of fiber, and that excessive amounts may also interfere in absorption of other nutrients ${ }^{(38)}$. In this context, it is important to consider the recommended dietary allowances of nutrients, proposed by research organizations in order to assure balance in such ingestion:

Carbohydrates: 45 to $65 \%$ of the total energy value Proteins: $46 \mathrm{~g}$ /day for women and $56 \mathrm{~g} /$ day for men Total fat: 20 to $35 \%$ of the total energy value

Polyunsaturated fat: $\omega-6$ from 5 to $10 \%$ and $\omega-3$ from 0.6 to $1.2 \%$ of the total energy value

Total fibers: $25 \mathrm{~g} /$ day for women and $38 \mathrm{~g} /$ day for men between 19-50 years

Source: Dietary Recommended Intakes, Institute of Medicine ${ }^{(39)}$

The literature does not generally advocate that supplementation is better than natural fiber-rich food, because the adequate ingestion of fruits, green and yellow vegetables and food rich in whole grains are summed up in a balanced and healthier ingestion of dietary fibers, which provides the ideal quantities of this nutrient in order to maintain proper metabolic activities.

\section{REFERENCES}

1. Vuksan V, Jenkins AL, Jenkins DJA, Rogovik AL, Sievenpiper JL, Jovanovski E. Using cereal to increase dietary fiber intake to the recommended level and 
the effect of fiber on bowel function in healthy persons consuming North American diets. Am J Clin Nutr. 2008;88(5):1256-62.

2. Pereira MA, O'Reilly E, Augustsson K, Fraser GE, Goldbourt U, Heitmann BL et al. Dietary fiber and risk of coronary heart disease - A pooled analysis of cohort studies. Arch Intern Med. 2004;164(4):370-6.

3. Samra RA, Anderson GH. Insoluble cereal fiber reduces appetite and shortterm food intake and glycemic response to food consumed 75 min later by healthy men. Am J Clin Nutr. 2007;86(4):972-9.

4. Forman MR, Hursting SD, Umar A, Barrett JC. Nutrition and Cancer Prevention: A Multidisciplinary Perspective on Human Trials. Annu Rev Nutr. 2004;24: 223-54.

5. Melanson KJ, Angelopoulos TJ, Nguyen VT, Martini M, Zukley L, Lowndes J et al. Consumption of whole-grain cereals during weight loss: effects on dietary quality, dietary fiber, magnesium, vitamin B-6, and obesity. J Am Diet Assoc. 2006;106(9):1380-8.

6. Seifert $S$, Watzl B. Inulin and oligofructose: review of experimental data on immune modulation. J. Nutr 2007;137(11 Suppl):2563S-7S.

7. Salman H, Bergman M, Djaldetti M, Orlin J, Bessler H. Citrus pectin affects cytokine production by human peripheral blood mononuclear cells. Biomed Pharmacother. 2008;62(9):579-82.

8. Ma Y, Hébert HR, Li W, Bertone-Johnson ER, Olendzki B, Pagoto SL et al. Association between dietary fiber and markers of systemic inflammation in the Women's Health Initiative Observational Study. Nutrition. 2008;24(10):941-9.

9. Ajani UA, Ford ES, Mokdad AH. Dietary fiber and C-reactive protein: findings from National Health and Nutrition Examination Survey Data. J Nutr. 2004;134(5):1181-5

10. Bulló M, Casas-Agustench P, Amigó-Correig P, Aranceta J, Salas-Salvadó J. Inflammation, obesity and comorbidities: the role of diet. Public Health Nutrition. 2007;10(10A):1164-72.

11. Wellen K, Hotamisligil GS. Inflammation, stress, and diabetes. J Clin Invest. 2005;115(5):1111-9.

12. Visscher TLS, Seidell JC. The public health impact of obesity. Annu Rev Public Health. 2001;22:355-75

13. Delzenne NM, Cani PD. A place for dietary fibre in the management of the metabolic syndrome. Curr Opin Clin Nutr Metab Care. 2005;8(6):636-40.

14. King DE, Mainous III AG, Egan BM, Woolson RF, Geesey ME. Effect of psyllium fiber supplementation on C-reactive protein: the trial to reduce inflammatory markers (TRIM). Ann Fam Med. 2008;6(2):100-6.

15. Delaney B, Nicolosi RJ, Wilson TA, Carlson T, Frazer S, Zheng $G$ et al. B-glucan fractions from barley and oats are similarly antiatherogenic in hypercholesterolemic syrian golden hamsters. J Nutr. 2003;133(2):468-95.

16. Xu H, Barnes GT, Yang Q, Tan G, Yang D, Chou CJ. Chronic inflammation in fat plays a crucial role in the development of obesity-related insulin resistance. $J$ Clin Invest. 2003;112(12):1821-30.

17. Hotamisligil GS. Role of Endoplasmic reticulum stress and c-Jun $\mathrm{NH}_{2}$-Terminal kinase pathways in inflammation and origin of obesity and diabetes. Diabetes. 2005;54(Suppl. 2):S73-8.

18. Nguyen NT, Magno CP, Lane KT, Hinojosa MW, Lane JS. Definition of Metabolic Syndrome-Scott M. Grundy. Association of Hypertension, Diabetes, Dyslipidemia, and Metabolic Syndrome with Obesity: Findings from the National Health and Nutrition Examination Survey, 1999 to 2004. J Am Coll Surg. 2008;207:928-34.

19. Grundy SM, Brewer HB, Cleeman JJI, Smith SC, Lefant JC. Definition of metabolic syndrome: report of the National Heart, Lung, Blood Institute/ American Heart Association Conference on Scientific Issues - Related to Definition. Circulation. 2004;109(3):433-8.

20. Matsushita K, Yatsuya H, Tamakoshi K, Wada K, Otsuka R, Takefuji S et al. Comparison of circulating adiponectin and proinflammatory markers regarding their association with metabolic syndrome in japanese men. Arterioscler Thromb Vasc Biol. 2006;26(4);871-6.

21. Real JMF, Pickup JC. Innate immunity, insulin resistance and type 2 diabetes. Trends in Endocrinol Metab. 2008;19(1):10-6.

22. Pischon T, Hub FB, Rexrode KM, Girman CJ, Mansonb JE, Rimmb EB. Inflammation, the metabolic syndrome, and risk of coronary heart disease in women and men. Atherosclerosis. 2008;197(1):392-9.

23. Haensel A, Mills PJ, Nelesen RA, Ziegler MG, Dimsdale JE. The relationship between heart rate variability and inflammatory markers in cardiovascular diseases-Alexander Haensel. Psychoneuroendocrinology. 2008;33(10):1305-12.

24. Rana JS, Nieuwdorp M, Jukema JW, Kastelein JJP. Cardiovascular metabolic syndrome - an interplay of, obesity, inflammation, diabetes and coronary heart disease. Diabetes Obes Metab. 2007;9(3):218-32.

25. Berg AH, Scherer PE. Adipose tissue, inflammation, and cardiovascular disease. Circ Res. 2005;96(9);939-49.

26. Slavin J. Impact of the proposed definition of dietary fiber on nutrient databases. Journal of Food Composition and Analysis 2003;16(3):287-91.

27. Gray J. Dietary Fibre Definition, Analysis, Physiology \& Health. Brussels: ILSI; 2006. p. 8-11. [Europe Concise Monograph Series].

28. King DE, Egan BM, Woolson RF, Mainous III AG, Al-Solaiman Y, Jesri A. Effect of a High-Fiber Diet vs a Fiber-Supplemented Diet on C-Reactive Protein Level. Arch Intern Med. 2007;167(5):502-6.

29. Oi L, Dam RMV, Liu S, Franz M, Mantzoros C, Hu FB. Whole-grain, bran, and cereal fiber intakes and markers of systemic inflammation in diabetic women. Diabetes Care. 2006;29(2):207-11.

30. Jensen MJ, Koh-Banerjee P, Franz M, Sampson L, Grønbæk M, Rimm EB. Whole grains, bran, and germ in relation to homocysteine and markers of glycemic control, lipids, and inflammation. Am J Clin Nutr. 2006;83(2): 275-83.

31. Jacobs DRJ, Andersen LF, Blomhoff R. Whole-grain consumption is associated with a reduced risk of noncardiovascular, noncancer death attributed to inflammatory diseases in the lowa Women's Health Study. Am J Clin Nutr. 2007:85(6):1606-14.

32. Oi L, Hu FB. Dietary glycemic load, whole grains, and systemic inflammation in diabetes: the epidemiological evidence. Curr Opin Lipidol. 2007;18(1):3-8.

33. Wärnberga J, Nova E, Romeo J, Moreno LA, Sjöström M, Marcos A. Lifestylerelated determinants of inflammation in adolescence. Br J Nutr. 2007:98 Suppl 1:S116-20.

34. Giugliano D, Ceriello A, Esposito K. The effects of diet on inflammation emphasis on the metabolic syndrome. J Am Coll Cardiol. 2006;48(4):677-85.

35. Lopez-Garcia E, Schulze MB, Meigs JB, Manson JE, Rifai N, Stampfer MJ. Consumption of trans fatty acids is related to plasma biomarkers of inflammation and endothelial dysfunction. J Nutr. 2005;135(3):562-6.

36. Nettleton JA, Steffen LM, Mayer-Davis EJ, Jenny NS, Jiang R, Herrington DM et al. Dietary patterns are associated with biochemical markers of inflammation and endothelial activation in the Multi-Ethnic Study of Atherosclerosis (MESA). Am J Clin Nutr. 2006;83(6):1369-79.

37. Geraldo JM, Alfenas RCG. Papel da dieta na prevenção e no controle da inflamação crônica - evidências atuais. Arq Bras Endocrinol Metab. 2008;52(6):951-67.

38. Khossousi A, Binns CW, Dhaliwal SS, Pal S. The acute effects of psyllium on postprandial lipaemia and thermogenesis in overweight and obese men. $\mathrm{Br} \mathrm{J}$ Nutr. 2008;99(5):1068-75.

39. Dietary Reference Intakes (DRls): Estimated Energy Requirements (EER) for Men and Women 30 Years of Age. Food and Nutrition Board, Institute of Medicine, National Academies [Internet] [cited 2009 Jan 9]. Available from: http://www.iom.edu/Global/News\%20Announcements/ /media/Files/ Activity\%20Files/Nutrition/DRIs/DRISummaryListing2.ashx 